\title{
Locally Advanced Soft Tissue Sarcoma
}

National Cancer Institute

\section{Source}

National Cancer Institute. Locally Advanced Soft Tissue Sarcoma. NCI Thesaurus. Code C153066.

Soft tissue sarcoma that has spread from its original site of growth to nearby tissues or lymph nodes. 